Arq. Bras. Med. Vet. Zootec., v.69, n.3, p.523-528, 2017

\title{
Acaricidal activity of leaves of Morus nigra against the cattle tick Rhipicephalus microplus
}

\author{
[Atividade acaricida das folhas de Morus nigra em \\ carrapato Rhipicephalus microplus] \\ A.C.S. Dantas ${ }^{1}$, D.P. Freire ${ }^{1}$, G.R.Souza ${ }^{1}$, J.R.G.S. Almeida ${ }^{1}$, L.A. Rolim ${ }^{1}$, \\ R.N. Castro $^{2}$, M.C. Horta ${ }^{1 *}$ \\ ${ }^{1}$ Universidade Federal do Vale do São Francisco - Petrolina, PE \\ ${ }^{2}$ Universidade Federal Rural do Rio de Janeiro - Seropédica, RJ
}

\begin{abstract}
The acaricidal activity of crude ethanolic extract and fractions from the leaves of Morus nigra (Moraceae) was carried out on female cattle ticks Rhipicephalus microplus, using the adult immersion test. The mortality and fertility of females exposed to different concentrations of hexane, chloroform and ethyl acetate fractions, as well as ethanolic extract of $M$. nigra with concentrations of 5,10 and $25 \mathrm{mg} / \mathrm{ml}$ were evaluated using three treatment groups, two control groups and triplicate tests. The study also identified the main phenolic compounds of the extract and fractions of this species by HPLC. The chloroform fraction of leaves of M. nigra $(25 \mathrm{mg} / \mathrm{mL})$ showed the best results for this species, obtaining $62.6 \%$ of inhibition of oviposition, 39.3\% of eggs eclosion average and $65.4 \%$ of effectiveness. HPLC analysis revealed the presence of phenolic compounds, which may be related to biological activity shown by the extracts, which can be used as an alternative control against $R$. microplus adult tick.
\end{abstract}

Keywords: tick control, acaricide, plant extract, mulberry, HPLC

\section{RESUMO}

A atividade acaricida do extrato etanólico bruto e das frações das folhas de Morus nigra (Moraceae) foi avaliada no carrapato Rhipicephalus microplus, utilizando-se o teste de imersão de fêmeas ingurgitadas. Foram avaliadas a mortalidade e a fertilidade das fêmeas ingurgitadas, expostas a diferentes concentrações $(5,10$ e $25 \mathrm{mg} / \mathrm{mL})$ das frações hexânica, clorofórmica e acetato de etila, bem como do extrato etanólico. Os testes foram realizados em triplicata. O estudo também identificou os principais compostos fenólicos do extrato e das frações dessa espécie por HPLC. A fração clorofórmica das folhas de M. nigra $(25 \mathrm{mg} / \mathrm{mL})$ apresentou o melhor resultado para essa espécie, obtendo-se $62,6 \%$ de inibição da oviposição, 39,3\% da eclosão dos ovos e 65,4\% de eficácia. A análise por HPLC revelou a presença de compostos fenólicos, os quais podem estar relacionados com a atividade biológica demonstrada pelos extratos, que podem ser utilizados como auxiliar no controle contra carrapato adulto de R. microplus.

Palavras-chave: controle de carrapatos, acaricida, extrato de planta, amora miúra, HPLC

\section{INTRODUCTION}

Popularly known as "Cattle tick", Rhipicephalus microplus is one of the most important vectors of pathogens to livestock (De Castro, 1997), being responsible for major damage to the agricultural sector (George et al., 2002). The control of cattle

Recebido em 5 de agosto de 2016

Aceito em 10 de outubro de 2016

* Autor para correspondência (corresponding author)

E-mail: horta.mc@hotmail.com tick is usually made using conventional synthetic chemicals, which causes the accelerated development of resistance to the active principle (Leal et al., 2003). Once resistance is established, producers often increase the pesticides dose or frequency of applications (Thullner, 1997). The intensive use of these chemicals has led to environmental 
contamination, exposure of rural workers and the presence of chemical residues in milk and meat, which causes a great concern to society and government agencies (Leal et al., 2003).

Due to many difficulties in controlling and combating this arthropod, the use of medicinal plants is an increasingly viable alternative in developing countries like Brazil, considering the great variability of species, low cost, easy availability and rapid degradation compared to other chemicals, as well as reduction of the contamination of environment, animals and men (Agnolin, 2010), these are the main reasons for the study of plants that have real acaricide effect (Benelli et al., 2016).

Morus nigra L. Moraceae, popularly known as "mulberry" is a species that has its origin in Asia, bearing fruit with a greater intensity and abundance, especially in Minor Asia and being fully acclimatized in Brazil (Cruz, 1979). Different groups of chemical compounds have been investigated on the genus Morus such as alkaloids, coumarins, flavonoids, triterpenes and steroids (Toshio et al., 2005).

In Chinese medicine, plants belonging to the genus Morus are used for its anti-inflammatory, diuretic, antitussive, analgesic and antipyretic effects (Nomura, 1988). Almeida et al. (2011) conducted a study on the hypoglycaemic potential of $M$. nigra leaves; and Oliveira et al. (2013) conducted a study to observe the toxicity of $M$. nigra tea leaves, concluding that the tea can be considered to have a low toxicity, and it also did not produce toxic effects on treated animals. However, the extract did not produce the expected hypoglycaemic effect. The crude ethanolic extract of the leaves of M. nigra was evaluated for antinociceptive activity in mice using models of nociception. The data suggested that the extract has antinociceptive activity, probably mediated via peripheral mechanisms (Souza et al., 2015).

Currently the plants with acaricide potential most researched are from the families Asteraceae, Fabaceae, Lamiaceae, Meliaceae, Solanaceae and Verbenaceae (Benelli et al., 2016). This study aimed to extract and evaluate the acaricidal activity of $M$. nigra leaves on the cattle tick $R$. microplus, using the adult immersion tests.

\section{MATERIALS AND METHODS}

Fresh leaves of Morus nigra (Moraceae) were collected at Ouro Verde farm, municipality of Casa Nova (Coordinates: S 0909'43"; W $\left.40^{\circ} 58^{\prime} 15^{\prime \prime}\right)$, State of Bahia, Brazil, in August of 2011. The taxonomic identification was made by José Alves de Siqueira Filho, a botanist from Centro de Recuperação de Áreas Degradadas da Caatinga (CRAD/UNIVASF). The voucher specimen (1764) was deposited at the Herbarium Vale do São Francisco (HVASF) of the Federal University of San Francisco Valley.

The dried and pulverized leaves were macerated with ethanol $95 \%$ at room temperature for $72 \mathrm{~h}$. The solution was filtered and concentrated under reduced pressure in a rotatory evaporator at 50 ${ }^{\circ} \mathrm{C}$, producing $69 \mathrm{~g}$ of crude ethanolic extract (Mn-EtOH). The fractions were obtained using a sequence of solvents to increase the polarity: hexane $(\mathrm{Mn}-\mathrm{HEX})$, chloroform $\left(\mathrm{Mn}-\mathrm{CHCl}_{3}\right)$ and ethyl acetate (Mn-AcOEt). After the extraction, the solutions were decanted, filtered and the solvents were removed by evaporation under reduced pressure.

The engorged female ticks were collected from a naturally infested herd, which were kept on the farms localized in the municipality of Petrolina, state of Pernambuco. These females were incubated for two weeks until the eggs were laid at a temperature of $27-28{ }^{\circ} \mathrm{C}$, and the relative humidity was $70-80 \%$. After hatching the eggs, two cows were artificially infested with the tick larvae, to ensure that these ticks were free of chemicals. $R$. microplus females in the later stages of engorgement, measuring more than 4.5 $\mathrm{mm}$, were collected from infested animals, washed with water and dried in paper toweling.

These females were used in the Adult Test Immersion (Drummond et al., 1973) to measure the acaricidal activity of extracts (leaves) from $M$. nigra against $R$. microplus adult engorged females. One hundred eighty (180) engorged females were separated into groups of ten (10), weighing approximately $0.2 \mathrm{mg}$, and were immersed in each solution for five minutes. Six groups were made: four treated (hexane, chloroform, ethyl acetate, and ethanol) at concentrations of 5,10 and $25 \mathrm{mg} / \mathrm{mL}$, two controls were also prepared, one containing only distilled water and another containing cremophor 
and distilled water, using three repetitions for each extract concentration tested as well as for the controls. Cremophor was used to facilitate the solubilization of the less hydrophilic extracts. After the immersion, the ticks were dried on paper toweling, placed in sterile Petri dishes and incubated at $27-28^{\circ} \mathrm{C}, 70-80 \%$ of relative humidity. After 14 days, the number of eggs per female were collected, then weighed and observed. The eggs were placed in glass tubes, incubated at the same conditions and after 14 days the tubes were observed and the hatching rates of the different treatments were estimated with the aid magnifying glass and compared to the controls.

The parameters were calculated as follows: Inhibition of oviposition $(\% \mathrm{IO})=[\mathrm{IO}$ (control) IO (treated)/IO (control)] x 100; percentage of estimated reproduction $(\% \mathrm{RE})=[(\mathrm{EW}) \times(\% \mathrm{E} \mathrm{x}$ $0,01) /(\mathrm{IFW})] \mathrm{x} 20,000$; reproduction control $(\% \mathrm{CR})=[\mathrm{CR}($ control $)-\mathrm{CR}($ treated $) /$ $\mathrm{CR}$ (control)] $\mathrm{x} 100$; where, $(\% \mathrm{IO})=$ percentage of inhibition of oviposition; $(\% \mathrm{RE})=$ percentage of reproductive efficiency; IFW = initial female weight; $\mathrm{EW}=$ egg weight, $(\% \mathrm{E})=$ percentage of eclosion and $(\% \mathrm{CR})=$ percentage of reproduction control.

Polyphenol identification analyses were carried out using a liquid chromatograph (Prominence LC-20AT, Shimadzu®, Japan) with a diode array detector (DAD, SPD-M20A) coupled to an LC Solution Chem Station data-processing station. The column used was a C18 Betasil $(250 \mathrm{~mm} \mathrm{x}$ $4.6 \mathrm{~mm} ; 5 \mu \mathrm{m}$; Thermo Fisher Scientific, Runcorn, UK), operated at $27^{\circ} \mathrm{C}$.

The mobile phase consisted of solvent A (ultrapure water and acetic acid, 99:1) and solvent B (methanol). The gradient (v/v) began with $38 \%$ of solvent $\mathrm{B}$, rising to $70 \%$ at $20 \mathrm{~min}$, $85 \%$ at $25 \mathrm{~min}$, and $100 \%$ at $30 \mathrm{~min}$, and remaining at this concentration for another 5 min. The injection volume was $20 \mu \mathrm{l}$, and the flow rate was $1 \mathrm{ml} . \mathrm{min}^{-1}$. Chromatograms for the phenolic compounds were recorded at $320 \mathrm{~nm}$ and $340 \mathrm{~nm}$. The phenolic compounds were identified by comparing with commercial standards of each identified compound using the retention time, the absorbance spectrum profile and also by running the samples after the addition of pure standards. The chemical standards were analyzed by the same RP-HPLCDAD method as phenolic extracts. Authentic markers available at the market were used for chromatographic comparison of data. Isoquercetin, gallic acid, protocatechuic acid, kaempferol-3- $O$-rhamnoside, vanillic acid and $p$ coumaric acid were supplied by Sigma-Aldrich ${ }^{\circledR}$ Chemie (Steinheim, Germany) for HPLC analysis with purity $\geq 99 \%$. The HPLC analysis was performed with all the extracts and fractions of M. nigra.

The data obtained were analyzed using the GraphPad Prism program version 5.0 and expressed as mean \pm S.E.M. Statistical significant differences between groups were calculated by the application of analysis of variance (ANOVA) followed by the Tukey test and confirmed using the $t$-Student test. Values were considered significantly different at $\mathrm{P}<0.05$.

This study was previously approved by the Human and Animal Ethic Commission of the Federal University of São Francisco Valley (10/07/2012).

\section{RESULTS}

The results for percentage of inhibition of oviposition (\% IO), hatching rate $(\% \mathrm{E})$, percentage of estimated reproduction (\% RE) and percentage of control of reproduction $(\% \mathrm{CR})$ of the extracts of leaves were demonstrated in Table 1.

$\mathrm{Mn}_{-} \mathrm{CHCl}_{3}$ gave the best answer at the concentration of $25 \mathrm{mg} / \mathrm{mL}$ for the percentage of inhibition of oviposition with $62.61 \%$ compared to control; in lower concentrations of inhibition was 4.2 and $6.65 \%$ for 5 and $10 \mathrm{mg} / \mathrm{mL}$, respectively. Mn-HEX, Mn-AcOEt and $\mathrm{Mn}$ $\mathrm{EtOH}$ showed no effect with a gradual increase of concentration, obtaining 12.10, 10.24 and $11.00 \%$ of inhibition for Mn-HEX, 9.52, 11.53 and $3.66 \%$ for Mn-AcOEt and 12.47, 8.62 and $19.03 \%$ for Mn- EtOH at concentrations of 5, 10 and $25 \mathrm{mg} / \mathrm{mL}$. There was no statistical difference in any of the phases. 
Table 1. Engorged female Rhipicephalus microplus ticks were exposed to different concentrations of extracts from the leaves of $M$. nigra

\begin{tabular}{|c|c|c|c|c|c|c|}
\hline $\begin{array}{l}\text { Extract } \\
(\mathrm{mg} / \mathrm{ml})\end{array}$ & $\begin{array}{l}\text { IFW - } \\
\text { initial } \\
\text { female } \\
\text { weight }\end{array}$ & $\begin{array}{c}\text { EW - egg } \\
\text { weight }\end{array}$ & $\begin{array}{l}\text { IO (\%) - } \\
\text { inhibition } \\
\text { oviposition }\end{array}$ & $\begin{array}{l}\text { E (\%) - } \\
\text { hatching }\end{array}$ & $\begin{array}{l}\mathrm{RE}(\%) \text { - } \\
\text { estimated } \\
\text { reproduction }\end{array}$ & $\begin{array}{l}\text { CR (\%) - } \\
\text { reproduction } \\
\text { control }\end{array}$ \\
\hline \multicolumn{7}{|l|}{ Hexane } \\
\hline 5 & $0.18 \pm 0.03$ & $0.08 \pm 0.01$ & $12.10 \pm 4.96$ & $88.78 \pm 17.71$ & $8268 \pm 1662$ & $20.55 \pm 15.21$ \\
\hline 10 & $0.18 \pm 0.02$ & $0.08 \pm 0.006$ & $10.24 \pm 6,24$ & $81.83 \pm 5.79$ & $6608 \pm 2058$ & $37.09 \pm 16.84$ \\
\hline 25 & $0.18 \pm 0.01$ & $0.18 \pm 0.008$ & $11.99 \pm 3.75$ & $71.50 \pm 10.97$ & $6069 \pm 1633$ & $42.10 \pm 13.02$ \\
\hline \multicolumn{7}{|l|}{ Chloroform } \\
\hline 5 & $0.18 \pm 0.01$ & $0.08 \pm 0.004$ & $4.2 \pm 5.22$ & $91,17 \pm 9.57$ & $8712 \pm 571.4$ & $9.15 \pm 14.96$ \\
\hline 10 & $0.19 \pm 0.02$ & $0.09 \pm 0.02$ & $6.65 \pm 10.40$ & $81.17 \pm 19.32$ & $6293 \pm 1539$ & $35.57 \pm 10.12$ \\
\hline 25 & $0.15 \pm 0.02$ & $0.02 \pm 0.01$ & $62.61 \pm 42.19$ & $39.33 \pm 49.33$ & $3334 \pm 4130$ & $65.44 \pm 41.86$ \\
\hline \multicolumn{7}{|l|}{ Ethyl acetate } \\
\hline 5 & $0.20 \pm 0.03$ & $0.09 \pm 0.01$ & $9.52 \pm 3.83$ & $84.83 \pm 10.25$ & $8012 \pm 815.4$ & $22.68 \pm 11.33$ \\
\hline 10 & $0.20 \pm 0.02$ & $0.09 \pm 0.01$ & $11.53 \pm 9.30$ & $76.50 \pm 6.94$ & $7130 \pm 906.5$ & $31.10 \pm 12.34$ \\
\hline 25 & $0.19 \pm 0.02$ & $0.09 \pm 0.009$ & $3.66 \pm 4.39$ & $73.17 \pm 24.90$ & $7378 \pm 2456$ & $28.37 \pm 27.05$ \\
\hline \multicolumn{7}{|l|}{ Ethanol } \\
\hline 5 & $0.21 \pm 0.009$ & $0.09 \pm 0.01$ & $12.47 \pm 7.00$ & $82.27 \pm 11.78$ & $7430 \pm 1553$ & $23.55 \pm 7.87$ \\
\hline 10 & $0.21 \pm 0.009$ & $0.1 \pm 0.01$ & $8.62 \pm 4.63$ & $90.60 \pm 2.85$ & $8557 \pm 719$ & $11.12 \pm 2.54$ \\
\hline 25 & $0.19 \pm 0.011$ & $0.08 \pm 0.003$ & $19.03 \pm 2.38$ & $86.37 \pm 9.70$ & $7479 \pm 1016$ & $22.57 \pm 3.49$ \\
\hline $\begin{array}{c}\text { Control } 1 \text { - } \\
\text { distilled water }\end{array}$ & $0.20 \pm 0.04$ & $0.1 \pm 0.02$ & & $96.33 \pm 6.35$ & $9457 \pm 817.7$ & \\
\hline $\begin{array}{c}\text { Control } 2 \text { - } \\
\text { distilled water } \\
\text { with cremophor }\end{array}$ & $0.18 \pm 0.04$ & $0.09 \pm 0.02$ & & $95.33 \pm 8.08$ & $9273 \pm 1402$ & \\
\hline
\end{tabular}

For the hatching rate, M. nigra the extract also showed no statistical difference in any of its phases as compared to control. $\mathrm{Mn}-\mathrm{CHCl}_{3}$ showed the highest inhibition of hatching of the eggs for this extracts, obtaining $39.33 \%$ of hatching in a concentration of $25 \mathrm{mg} / \mathrm{mL}$, at lower concentrations $(5$ and $10 \mathrm{mg} / \mathrm{mL})$ showed $91.17 \%$ and $81.17 \%$ of hatching. The Mn-HEX concentration of $25 \mathrm{mg} / \mathrm{ml}$, obtained $71.5 \%$ of hatching, Mn-AcOEt and Mn-EtOH (2.5\%) hatched 73.17 and $86.37 \%$, respectively, of their eggs. There was no statistical difference between extracts and controls.

M. nigra extract had an effect on the reproduction of the percentage of estimated reproduction, especially $\mathrm{Mn}-\mathrm{CHCl}_{3}$, with a decreased reproduction estimated in 3334 at a concentration of $25 \mathrm{mg} / \mathrm{mL}$, compared to the control group with 9457, at the concentrations 5 and $10 \mathrm{mg} / \mathrm{mL}$, obtaining 6608 and 6069 , respectively. In the same concentrations, MnHEX presented 8268, 6608 and 6069; MnAcOEt 8012, 7130 and 7378; and Mn-EtOH 7430, 8557 and 7479, respectively.

The acaricidal activity of $M$. nigra extract was most evidenced in the chloroform phase, increasing efficiency in $65.44 \%$ at a concentration of $25 \mathrm{mg} / \mathrm{mL}$. At lower concentrations (5 and $10 \mathrm{mg} / \mathrm{mL}$ ), was obtained 9.15 and $35.5 \%$. The hexane extract also showed insecticide activity when compared to the control group, obtaining $20.55,37.09$ and $42.10 \%$ for concentrations of 5,10 , and $25 \mathrm{mg} / \mathrm{mL}$. The crude ethanol extract and ethyl acetate showed no response to gradually increasing concentrations $(5,10$ and $25 \mathrm{mg} / \mathrm{mL})$ with $22.68,31.10$ and $28.37 \%$ for $\mathrm{Mn}-\mathrm{AcOEt}$; and 23.55, 11.12 and $22.57 \%$ for Mn-EtOH. 
There was no statistical difference between control 1 (distilled water) and control 2 (distilled water with cremophor), showing that the cremophor surfactant did not demonstrated any toxicity to the ticks.

The composition profile of phenolic compounds of $M$. nigra was analyzed by HPLC-DAD. Based on the chromatograms (not shown in this paper), it was possible to identify the presence of the flavonoids isoquercetin and kaempferol-3- $O$ rhamnoside in Mn-EtOH and Mn-HEX; rutin, isoquercetin and kaempferol-3- $O$-rhamnoside in Mn-AcOEt. However, it was not possible to identify the substances present in $\mathrm{Mn}-\mathrm{CHCl}_{3}$ by comparison of retention time and maximum absorption spectra at the analytical standards, therefore no similarity to any of the evaluated analytical standards. These three compounds with retention times at 8.88, 20.61 and 20.84 minutes are under investigation.

\section{DISCUSSION}

Several studies confirm the presence of the classes of secondary metabolites in the leaves of Morus nigra. Song et al. (2009) confirm the presence of flavonoids, phenolic compounds, such as anthocyanins and alkaloids in the leaves and fruits of plants of the genus Morus. Flavonoids have been recognized to possess antioxidant, anti-inflammatory, antiallergic and hepatoprotective activities, among other functions. Anthocyanins also have a potent antioxidant and anti-inflammatory activity. Padilha et al. (2010) confirmed the presence of steroids and triterpenes in plant extract.

This is the first study that evaluated the acaricidal activity of $M$. nigra. It is more likely to find biological activity in plants targeted for its use in popular medicine in that the plants chosen at random (Pivoto et al., 2010). However, the species studied in this work were selected for their abundance in the Caatinga biome and also for having classes of substances that may be unpublished as the acaricidal effect.

For $M$. nigra, the chloroform fraction reached $62.61 \%$ effective and presented an acaricidal action, both on female fertility and the viability of the eggs. The percentage of hatching was only
$39.33 \%$ and the inhibition of oviposition reached $62.61 \%$. The chloroform fraction was characterized having more apolar compounds. In nonpolar extract, substances can be found, such as steroids, terpenes, acetophenones, aglycone, waxes, sapogenins, iridoids and sesquiterpenes, highly lipophilic substances (Cechinel-Filho and Yunes, 1998; Sonaglio et al., 2010). Terpenes are reported in the literature as having acaricidal activity and are therefore the subject of several studies. This class of metabolites covers a wide range of plant-derived substances and their ecological importance as defensive is well established. Several monoterpenes were isolated and evaluated for toxicity against different insects and arthropods (Viegas Junior, 2003). According to Romero et al. (2008), terpenes and its derivatives such as monoterpenes and sesquiterpenes are substances found commonly in the essential oils and form together with the phenylpropanoid potent natural insecticides like pyrethroids. The chlorofom extract of the leaves of $M$. nigra in low concentrations showed noticeable toxicity levels, similar to other plant extracts. Similar results to ours were obtained by Giglioti et al. (2011) that evaluated the effect of azadiractin against $R$. microplus, obtained an efficacy of $61.6 \%$ in a $2.5 \%$ concentration, concluding that the isolated substance has effect in vitro against ticks. The experiment reported preliminary results, but provided clear evidence those fractions of leaves of $M$. nigra have a potential pesticide effect and seems to be an alternative control auxiliary for ticks. According to the results obtained, we can conclude that the extract prepared from $M$. nigra contains substances which have a deleterious action on the reproduction of $R$. microplus females. HPLC analysis revealed the presence of phenolic compounds, which may be related to biological activity shown by the extracts. Further complementary studies are needed to establish the nature of the other components contained in $M$. nigra that have an acaricidal effect.

\section{ACKNOWLEDGEMENTS}

We would like to thank Maíra Guimarães and Thalita Dias for their valuable help during the laboratory tests. This work was supported by CNPq. 


\section{REFERENCES}

AGNOLIN, C.A.; OLIVO, C.J.; LEAL, M.L.R. et al. Eficácia do óleo de citronela (Cymbopogon nardus $\mathrm{L}$. Rendle) no controle de ectoparasitas de bovinos. Rev. Bras. Plantas Med., v.12, p.482-487, 2010.

ALMEIDA, J.R.G.S.; GUIMARÃES, A.L.; OLIVEIRA, A.P. et al. Evaluation of hypoglycemic potential and pre-clinical toxicology of Morus nigra $\mathrm{L}$. (Moraceae). Lat. Am. J. Pharm., v.30, p.96-100, 2011.

BENELLI, G.; PAVELA, R.; CANALE, A. et al. Tick repellents and acaricides of botanical origin: a green roadmap to control tick-borne diseases? Parasitol. Res., v.115, p.2545-2560, 2016.

CECHINEL-FILHO, V.; YUNES, R.A. Estratégias para a obtenção de compostos farmacologicamente ativos a partir de plantas medicinais. Conceitos sobre modificação estrutural para otimização da atividade. Quim. Nova., v.21, p.99-105, 1998.

CRUZ, G.L. Dicionário de plantas úteis no Brasil. Rio de Janeiro: Civilização Brasileira, 1997. 599p.

DE CASTRO, J. Sustainable tick and tick-borne disease control in livestock improvement in developing countries. Vet. Parasitol., v.2-3, p.77-97, 1979.

DRUMMOND, R.O.; ERNST, S.E.; TREVINO, J.L. et al. Boophilus annulatus and Boophilus microplus: laboratory tests of insecticides. J. Econ. Entomol., v.66, p.130-133, 1973.

GEORGE, S.E.; DAVEY, R.B.; POUND, J.M. Introduced ticks and tick-borne diseases: the threat and approaches to eradication. Vet. Clin. N. Am. Food Anim. Pract., v.18, p.401-416, 2002.

GIGLIOTI, R.; FORIM, M.R.; OLIVEIRA, H.N. et al. In vitro acaricidal activity of neem (Azadirachta indica) seed extracts with known azadirachtin concentrations against Rhipicephalus microplus. Vet. Parasitol., v.181, p.309-315, 2011.

LEAL, A.T.; FREITAS, D.R.J.; VAZ JÚNIOR, I.S. Perspectivas para o controle do carrapato bovino. Acta Sci. Vet., v.31, p.1-11, 2003.

NOMURA, T. Phenolic compounds of the mulberry tree and related plants. In: HERZ, W.; GRISEBACH, H.; KIURBY, G.W.; TAMM, C.H. Progress in the chemistry of organic natural products. Vienna: Springer Publishing, 1988. p.87.
OLIVEIRA, A.C.B.; OLIVEIRA, A.P.; GUIMARÃES, A.L. et al. Avaliação toxicológica préclínica do chá das folhas de Morus nigra L. (Moraceae). Rev. Bras. Plant. Med.,v.15, p.244-249, 2013.

PADILHA, M.M.; MOREIRA, L.Q.; MORAIS, F.F. et al. Estudo farmacobotânico das folhas de amoreirapreta, Morus nigra L., Moraceae. Rev. Bras. Farmacogn., v.20, p.621-626, 2010.

PIVOTO, F.L.; BUZATTI, A.; KRAWCZAK, F.S. et al. Ação acaricida in vitro de Tropaeolum majus sob teleóginas de Rhipicephalus (Boophilus) microplus. Ciên. Rural, v.40, p.2141-2145, 2010.

ROMERO, C.G. Fitoterapia em Ganaderia ecológical orgânica flora medicinal de Espana y Panama. [Luxembourg]: Edita, 2008. p.111.

SONAGLIO, D.; ORTEGA, G.G.; PETROVICK, P.R.; BASSANI, V.L. Desenvolvimento tecnológico e produção de fitoterápicos. In: SIMÕES, C.M.O.; SCHENKEL, E.P.; GOSMANN, G. et al. Farmacognosia: da planta ao medicamento. 6.ed. Porto Alegre: UFRGS, 2010. 1104p.

SONG, W.; WANG, H.J.; BUCHELI, P. et al. Phytochemical profiles of different mulberry (Morus sp.) species from China. J. Agricult. Food Chem.,v.57, p.33-40, 2009.

SOUZA, G.R.; SILVA, J.C.; OLIVEIRA-JUNIOR, R.G. et al. Atividade antinociceptiva do extrato etanólico das folhas de Morus nigra L. (Moraceae). Rev. Ciênc. Farm. Basic. Aplicada, v.36, p.137-142, 2015.

TOSHIO, F.; KIYOSHI, K.; SUMIO.T. Antimicrobial activity of 2-arylbenzofurans from Morus species against methicillin-resistant Staphylococcus aureus. Fitoterapia, v.76, p.708-711, 2005.

THULLNER, F. Impact of pesticide resistance and network for global pesticide resistance management based on a regional structure. World Animal Review $R M Z$, v.89, p.41-47, 1997.

VIEIRA JUNIOR, C. Terpenos com atividade inseticida: uma alternativa para o controle químico de insetos. Quim. Nova,v.26, p.390-400, 2003. 